\title{
Educational technology on COVID-19 for families of children and adolescents with sickle cell disease
}

\author{
Tecnologia educativa sobre a COVID-19 para famílias de crianças e adolescentes com doença falciforme
} Tecnología educativa sobre COVID-19 para familias de niños y adolescentes con anemia de células falciformes

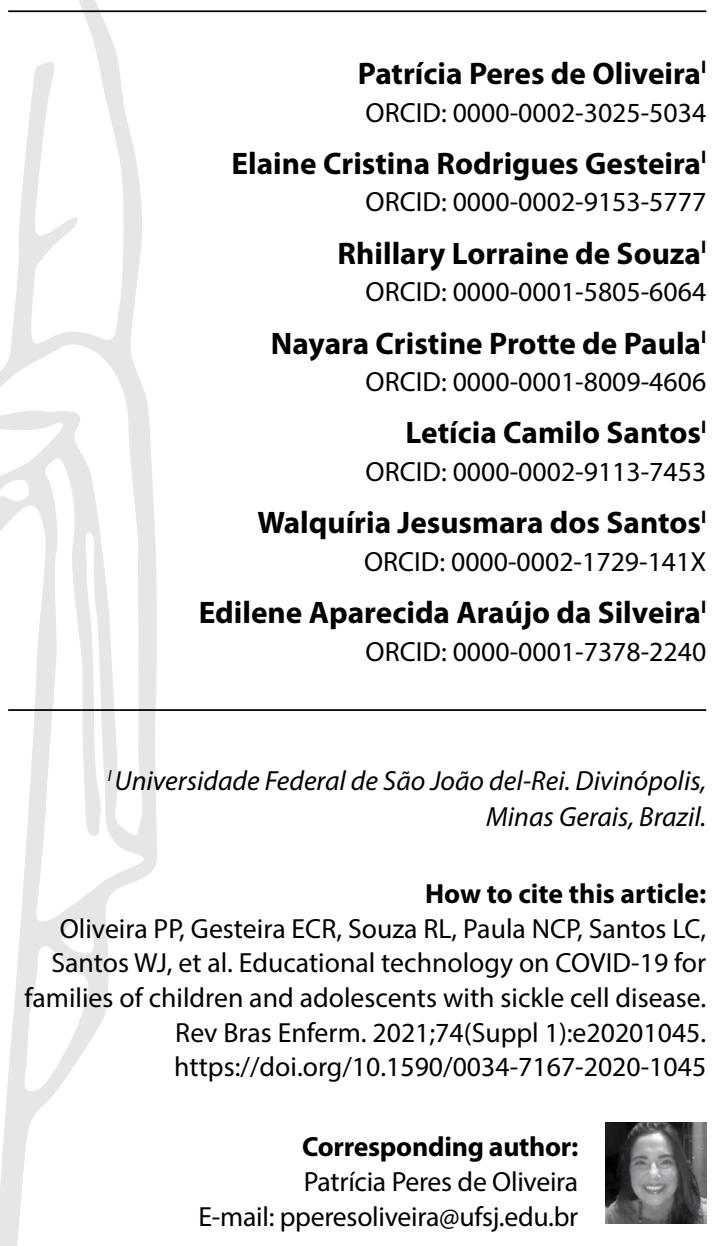

EDITOR IN CHIEF: Dulce Barbosa ASSOCIATE EDITOR: Ana Fátima Fernandes

Submission: 09-14-2020

Approval: 02-07-2021

\section{ABSTRACT}

Objective: to construct and validate educational technology on COVID-19 and essential care for families of children/adolescents with sickle cell disease. Methods: this is a methodological study, in three stages: 1) elaborated educational technology, using the Doak, Doak and Root theoretical-methodological model; 2) content and appearance validation by the content validity coefficient. Delphi technique was applied in two rounds (Delphi I [12 judges]/Delphi II [11 judges]); 3) conducting a pilot test with six families. Results: "Sickle cell disease and COVID-19: essential care" included: consequences of COVID-19 in sickle cell disease, guidelines for reducing the risks of contracting the virus and having complications, signs and symptoms of COVID-19, guidelines in case of child/adolescent with suspicion or symptoms of COVID-19. Global content validity coefficient (Delphi II): 0.98 . Conclusion: educational technology presented content and appearance validity for families of children/adolescents with sickle cell disease, related to COVID-19. Descriptors: Anemia, Sickle Cell; Family Nursing; Coronavirus Infections; Educational Technology; Validation Studies.

\section{RESUMO}

Objetivo: construir e validar tecnologia educativa sobre COVID-19 e os cuidados essenciais para famílias de crianças/adolescentes com doença falciforme. Métodos: estudo metodológico, em três etapas: 1) elaborado tecnologia educativa, utilizando modelo teórico-metodológico de Doak, Doak e Root; 2) validação de conteúdo e aparência pelo coeficiente de validade de conteúdo. Executou-se técnica de Delphi em duas rodadas (Delphi I [12 juízes] /Delphi II [11 juízes]); 3) realização de teste piloto com seis famílias. Resultados: a tecnologia educativa "Doença falciforme e COVID-19: cuidados essenciais" contemplou: consequências da COVID-19 na doença falciforme, orientações para reduzir os riscos de contrair o vírus e ter complicações, sinais e sintomas da COVID-19, orientações em caso de criança/adolescente com suspeita ou sintomas da COVID-19. Coeficiente de validade de conteúdo global (Delphi II): 0,98. Conclusão: a tecnologia educativa apresentou validade de conteúdo e aparência para famílias de crianças/adolescentes com doença falciforme, relacionada à COVID-19. Descritores: Enfermagem Familiar; Anemia Falciforme; Infecções por Coronavirus; Tecnologia Educacional; Estudos de Validação.

\section{RESUMEN}

Objetivo: construir y validar tecnología educativa sobre COVID-19 y cuidados esenciales para familias de niños/adolescentes con anemia falciforme. Métodos: estudio metodológico, en tres etapas: 1) tecnología educativa elaborada, utilizando el modelo teórico-metodológico de Doak, Doak y Root; 2) validación de contenido y apariencia por el coeficiente de validez de contenido. La técnica Delphi se aplicó en dos rondas (Delphi I [12 jueces]/Delphi II [11 jueces]); 3) realización de una prueba piloto con seis familias. Resultados: la tecnología educativa "Enfermedad de células falciformes y COVID-19: cuidados esenciales" incluyó: consecuencias de COVID-19 en la enfermedad de células falciformes, directrices para reducir los riesgos de contraer el virus y complicaciones, signos y síntomas de COVID-19, directrices en caso de un niño/adolescente con sospecha o síntomas de COVID-19. Coeficiente de validez de contenido global (Delphi II): 0,98. Conclusión: la tecnología educativa presentó validez de contenido y apariencia para familias de niños/adolescentes con anemia falciforme, relacionada con COVID-19.

Descriptores: Anemia de Células Falciformes; Enfermería de la Familia; Infecciones por Coronavirus; Tecnología Educacional; Estudios de Validación. 


\section{INTRODUCTION}

Sickle cell disease (SCD) is one of the most common hemoglobinopathies in the world. It is estimated that around $5 \%$ of the world population has some structural and/or functional change that affects hemoglobin. The World Health Organization has identified SCD as a major public health concern due to its biopsychosocial incidence and complexity ${ }^{(1-2)}$. Accurate data regarding the number of individuals with $S C D$ in the world are scarce, however it is assumed that approximately 300,000 children are born with the disease each year. Furthermore, it is known that these births are concentrated mainly in Nigeria, Democratic Republic of Congo, and India(3).

Currently, Brazil has between 25,000 and 30,000 people with SCD and about 7 million with sickle cell trait. Approximately 3,500 live children/year with SCD are born, although the prevalence varies widely across the country. The State of Bahia has the highest incidence of SCD (1:650), followed by the State of Rio de Janeiro $(1: 1,300)$; the third place is represented by four states (Pernambuco, Maranhão, Minas Gerais, and Goiás), with an incidence of 1: 1,400 live births $s^{(4)}$.

The pandemic due to COVID-19, caused by the new coronavirus (Sars-CoV-2), is having a devastating effect on socioeconomic and health indicators in countries around the world, including Brazil, due to the additional financial burden to support the management system to combat the impact of COVID-19 and the risk of overloading health services ${ }^{(2)}$. Common clinical manifestations seen in people with SCD infected with Sars-CoV-2 include cough, fever, dyspnea, anosmia and ageusia. Most patients with COVID-19 can have a mild course of the disease, while others can develop severe clinical manifestations $s^{(5)}$.

It is significant to address the impact of the current COVID-19 pandemic on people with SCD who are particularly vulnerable. This new strain of coronavirus 2 (Sars-CoV-2) with severe acute respiratory syndrome causes pneumonia of varying severity, with severe illness in approximately $15 \%$ to $20 \%$ of infected patients. The main clinical presentations may include persistent dry cough, fever, and dyspnea ${ }^{(5-6)}$.

The UK reported a higher number of deaths than in Europe, with a higher risk of mortality in groups of blacks, Asians and ethnic minorities. In particular, Afro-descendants had a 1.9-fold higher risk of mortality compared to Caucasians. Similar statistics have also been observed in many ethnic groups in South Asia. People with SCD are predominantly of African descent and are more susceptible to infections due to manifestations such as functional asplenia and impaired complement activation ${ }^{(6)}$. Thus, this population is potentially at high risk of morbidity and mortality ${ }^{(2,5)}$.

The main cause of concern in people with SCD and their families is that, because they are immunocompromised, they may suffer acute and chronic complications that require hospitalization and close contact with the health system ${ }^{(7-8)}$.

In the context of the current pandemic, it is possible to identify some challenges for the families of children and adolescents with $\mathrm{SCD}$, namely: diagnosis and treatment of uncertain infections; when there is a need for in-hospital antibiotic therapy, which makes social isolation difficult; risk of contamination by the Sars-CoV-2 virus, when there is no effective organization in the flow of care for blood transfusions; consequences of social isolation, which can delay the performance of exams and therapeutic management if people with SCD and/or their families are not properly guided by the services available in the municipalities ${ }^{(7-8)}$.

In this context, it is worth noting that the families of children and adolescents with SCD face difficulties in managing this disease on a daily basis; experience recurrent hospitalizations, changing family dynamics, which must continually adjust to new situations imposed by the disease ${ }^{(5,8)}$. However, in the current pandemic scenario, families in these conditions need to obtain clear and objective knowledge from the multidisciplinary team, especially nurses, par excellence in care, in order to empower them for the management of children and adolescents with SCD in times of COVID-19.

Although the dissemination and access to information about COVID-19 is happening on a large scale, it is essential to disseminate specific information to this audience. For this, the use of educational technologies (ET) has been shown to be ideal, since it favors the communication of nurses with these families through a clear verbal and visual language that contributes to nursing care $^{(9)}$.

\section{OBJECTIVE}

To construct and validate educational technology on COVID-19 and essential care for families of children/adolescents with sickle cell disease.

\section{METHODS}

\section{Ethical aspects}

The study was approved by the Research Ethics Committee of Universidade Federal de São João del-Rei. The participants involved in the research signed the Informed Consent Form (ICF). The ethical precepts of research with human beings were respected, based on Resolutions 466/2012 and 580/2018 of the Brazilian National Health Council (Conselho Nacional de Saúde).

\section{Study design, place, and period}

It is a methodological research with a quantitative approach. The research followed the benchmark of studies to improve the SQUIRE quality of the Equator network. It was developed in three stages; the first was related to the instrument construction (brochure); the second, regarding the validation of its content and appearance by the judges, points out that the Delphi technique was applied in two rounds (Delphi I [12 judges]; Delphi II [11 judges]); in the third, a pilot test was carried out.

The first stage, instrument construction, took place from April to May 2020 and was guided by the Doak, Doak and Root theoretical and methodological framework ${ }^{(10)}$, which indicates certain imperative guidelines for planning the preparation of educational materials $s^{(9-10)}$, namely: a) determining the target audience - although it appears to be an evident step, it can often be neglected; $b$ ) establishing learning objectives, which need to be compatible with behaviors and actions, in addition to aiming 
at educational interventions; c) construction, it is necessary to use the active voice in writing, since reading becomes uncomplicated and easier for the reader to perpetrate the action; d) writing short sentences and avoid the use of technical terms, as it makes understanding difficult; e) having interactions that can make the orientations simpler to apprehend and be remembered; f) testing to ensure quality ${ }^{(9-10)}$.

After this stage, the content and appearance were assessed by nurse judges, experts in the field of hemoglobinopathies, from late May to July 2020. This process was conducted using the Delphi technique. The next phase, referring to the pilot study, took place with families followed up by the "Educating on Sickle Cell" Extension and Research Group at a federal university in Minas Gerais, between July and August 2020.

\section{Sample, and inclusion and exclusion criteria}

In the ET validation stage, Pasquali's proposal ${ }^{(11)}$ was followed, in order to reach the number of judges, i.e., six to 20 experts ${ }^{(11)}$. It was decided to invite a larger number, considering that some might not respond or refuse the invitation.

This process was directed through the analysis of judges selected for the study, chosen intentionally, through the appreciation of curricula in the Lattes Platform of the Brazilian National Council for Scientific and Technological Development (CNPq - Conselho Nacional de Desenvolvimento Científico e Tecnológico). To this end, we used the simple search form, in the field "search for", category "subject", using the term "sickle cell disease", professional practice: nursing area. Also, 324 doctors were identified.

For the screening of judges, in order to validate material content and appearance, Fehring's model ${ }^{(12)}$ was adapted and used, since it conceives a maximum score of 14 points. However, for this choice, a minimum score of five points was given, namely: master's degree in nursing or related areas (mandatory criterion); dissertation on hemoglobinopathies ( 2 points); thesis focusing on hemoglobinopathies ( 2 points); certificate or title of specialist in nursing in hemotherapy and hematology or nursing in oncology and hematology (1 point); research (es) addressing SCD in the last five years (3 points); authorship in at least one article, in the last three years, covering SCD (3 points); experience in assisting people with SCD for at least one year (3 points) ${ }^{(11)}$.

After the search, a total of 45 eligible judges were reached. They received an invitation letter by e-mail, with a deadline of up to 15 days to return the instrument, in addition to ICF, with the necessary instructions to carry out brochure analysis and validation $^{(12)}$.

In the pilot test stage, the sample of families of children/ adolescents with SCD was designed based on the records of that service, comprising 40 families. Considering that, in a pilot study, a percentage of approximately $10 \%$ of the sample is recommended as an effective amount ${ }^{(14)}$. Four families were calculated and it was decided to work with six of them to ensure greater efficiency. The sample selection happened for convenience with families assisted by the "Educating on Sickle Cell" Extension and Research Group of a federal university in Minas Gerais, meeting the following inclusion criteria: age from 18 years old and being monitored by the group for at least one year.

\section{Study protocol}

In the first stage, a search was performed in the databases Medical Literature Analysis and Retrieval System Online (MEDLINE), Cumulative Index to Nursing and Allied Health Literature (CINAHL) and Latin American Literature in Health Sciences (LILACS), using the Health Sciences Descriptors (DeCS/MeSH) "Anemia, Sickle Cell","Coronavirus Infections", with the AND Boolean operator. Works published in 2019 and 2020 were considered, since COVID-19 was detected in Wuhan, China, in December 2019. In addition to searching the databases, materials published in the World Health Organization (WHO) were used, Center for Disease Control and Prevention (CDC), Sickle Cell Disease Association of America (SCDAA) and Brazilian Association of Hematology, Hemotherapy and Cell Therapy (ABHH - Associação Brasileira de Hematologia, Hemoterapia e Terapia Celular).

The work of making the brochure was carried out by three of the authors, including image design, typography, choice of colors, and diagramming. The process, as it was carried out, was sent to the researchers for feedback and approval. The art was made using Adobe Photoshop CC, 2017.

The completed instrument for the assessment was built with the Google Docs tool, adapted from Perdigão et al ${ }^{(9)}$, with initial information on the characterization of participants and items to be assessed (objectives, structure, presentation, relevance and content itself). The judges were asked to assess the ET as to content and appearance, with the answers given by a Likert-type scale: 1 ) inadequate (I); 2 ) partially adequate (PA); 3 ) adequate (A); 4) totally adequate (TA). There was a space where the judges could suggest changes and improvements.

This process was conducted by the Delphi technique. Thus, the experts answered, through rounds, an evaluative questionnaire. Of the 45 possible judges initially selected, 12 agreed to participate in the brochure assessment, corresponding to the first round (Delphi I), when there were suggestions for changes in the material for its improvement. All suggestions were considered relevant; and, after adjustments, the feedback of the responses was sent along with the protocol, configuring the second round (Delphi II), a stage in which there was the participation of 11 judges (it is noteworthy that these judges participated in the two Delphi rounds).

The third stage referred to the pilot test carried out with families of children/adolescents, with SCD followed by the "Educating on Sickle Cell" Extension and Research Group. After the validation process with judges, the instrument was applied by three of the authors, who followed a standard operating procedure, containing conceptual and operational definitions.

Families were instructed on how to participate, guarantee anonymity and confidentiality of information, and signed ICF. Then, they answered a validation questionnaire adapted from Perdigão et $\mathrm{al}^{\left({ }^{(9)}\right.}$, containing the instructions for filling it out and the items to be assessed regarding the objectives, style of writing, organization, appearance and motivation.

\section{Analysis of results, and statistics}

The data were organized in a spreadsheet using the statistical software Microsoft Excel, 2020. After being tabulated, they were analyzed using descriptive statistics. 
To perform the analysis of experts' agreement, the method known as content validity coefficient (CVC) was adopted, which measures the percentage of specialists who are in agreement on certain aspects of the instrument and its items. The item with more than $80 \%$ agreement among judges (assessed as "adequate" or "totally adequate") and a CVC $>0.78$ was considered valid(10). CVC was calculated by adding the number of responses marked " 3 " or " 4 " by the judges, dividing the result by the total number of responses. Moreover, judges' suggestions were accepted.

\section{RESULTS}

The preparation of the first version was carried out based on the 21 studies identified in the databases and selected organizations. In the brochure construction, it was evident that, to the initial format, no previously listed items were added. The changes made consisted essentially of structure and presentation (concordance and spelling, adaptation of vocabulary to the target population, insertion of images about the correct use of the homemade or surgical mask and hand hygiene, in addition to changing the position of the topics). The finished brochure had five topics.

The "Sickle Cell Disease and COVID-19: essential care" ET was organized into the following categories: what are the consequences of COVID-19 in SCD; guidelines for reducing the risk of catching the virus and having complications from COVID-19 and SCD; what to do if a child/adolescent is suspected of having a coronavirus; what are the signs and symptoms of COVID-19; what to do if a child/adolescent has symptoms of COVID-19, in addition to presenting a succinct part of the bibliography used.

Initially, textual elaboration was carried out. Afterwards, the authors made images; these were arranged close to the texts to which they allude, in order to represent some information of the ET. Text was written with a non-stylized font, Arial font, body 11 for information and subtitles and Arial Black 21 font for the cover title, and for these last two, bold font was also used. For the information that needed more prominence, the use of text boxes, with size 11 and bold font, was used. A4 matte coated paper with black letters for text and color printing was used.

After the ET preparation, content and appearance were validated. The expert committee was composed of 12 professional nurses in the first round of assessment and 11 in the second, with loss of one due to non-response in the electronic form. Ten (83.30\%) doctors and two (16.70\%) masters participated. In Delphi II, a master did not contribute to ET validation. The minimum age of specialists was 28 years old and maximum of 55 years old (mean of 43.00 and standard deviation of 9.40 in Delphi l; mean of 41.90 and standard deviation of 9.02 in Delphi II), whose time training was over 10 years for $58.30 \%$ (seven) judges; $25.00 \%$ (three) between six and 10 years of training and; $16.70 \%$ (two) with less than five years of graduation in higher education.

The result obtained from the CVC regarding the "objectives" item was 0.93; in structure and presentation, 0.94; in relevance, 1.0. Global CVC, on the other hand, scored 0.95 , ensuring the validity of the brochure content and appearance for use in the target population (Table 1).

Table 1 describes the final consensus among judges regarding the analyzed items of ET content and appearance on COVID-19 and the essential care for families of children/adolescents with SCD, who obtained agreement ("adequate" and "totally adequate") according to the assessment criteria ${ }^{(8)}$.

As shown in Table 1, it was observed that all items were above the recommended (CVC> 0.78)

In the comments, the judges pointed out changes in relation to the structure and presentation. In the item "Is the brochure easy to read and understand?" (CVC $=0.81)$, judges' suggestions in the first round (Delphi I) were: replace the term sanitize with clean and sodium hypochlorite with bleach; add to the term "isopropyl alcohol" the word "liquid" in parentheses.

Table 1 - Content validity coefficient for all items (objectives, structure and presentation, relevance and global index) according to judges' analysis, Divinópolis, Minas Gerais, Brazil

\begin{tabular}{|c|c|c|}
\hline Items & $\begin{array}{l}\text { CVC } \\
\text { Delphi I }\end{array}$ & $\begin{array}{c}\text { CVC } \\
\text { Delphi II }\end{array}$ \\
\hline Objectives & 0.91 & 0.96 \\
\hline $\begin{array}{l}\text { 1. Does the brochure include essential care for } \\
\text { families of children and adolescents with SCD over } \\
\text { COVID-19? }\end{array}$ & 0.92 & 0.98 \\
\hline $\begin{array}{l}\text { 2. Does it provide relevant information and } \\
\text { guidance, contributing to the health education } \\
\text { process? }\end{array}$ & 0.94 & 0.98 \\
\hline $\begin{array}{l}\text { 3. Is it effective for maintaining COVID-19-related } \\
\text { self-care for families of children and adolescents } \\
\text { with SCD? }\end{array}$ & 0.89 & 0.98 \\
\hline $\begin{array}{l}\text { 4. Does it have the ability to promote changes in } \\
\text { behavior and attitude? }\end{array}$ & 0.89 & 0.91 \\
\hline $\begin{array}{l}\text { 5. Can this brochure circulate in the scientific } \\
\text { community in the area? }\end{array}$ & 0.92 & 0.91 \\
\hline $\begin{array}{l}\text { 6. Can this brochure be implemented in the daily } \\
\text { clinical practice of nurses working in the area of } \\
\text { hemoglobinopathies? }\end{array}$ & 0.89 & 0.98 \\
\hline Structure and Presentation & 0.90 & 0.97 \\
\hline $\begin{array}{l}\text { 1. Is the information presented clearly and } \\
\text { objectively? }\end{array}$ & 0.94 & 0.96 \\
\hline 2. Is the information presented scientifically correct? & 0.96 & 0.98 \\
\hline 3. Does the brochure have a logical sequence? & 0.94 & 0.94 \\
\hline $\begin{array}{l}\text { 4. Is the information well structured in terms of } \\
\text { concordance and spelling? }\end{array}$ & 0.85 & 0.98 \\
\hline 5. Is the font suitable? & 0.94 & 0.98 \\
\hline 6. Is the font size adequate? & 0.92 & 0.98 \\
\hline 7. Is the spacing between lines adequate? & 0.94 & 0.96 \\
\hline 8. Is the brochure easy to read and understand? & 0.81 & 0.96 \\
\hline 9. Are the images adequate? & 0.85 & 0.98 \\
\hline $\begin{array}{l}\text { 10. Do the images portray what one really wants to } \\
\text { pass on information? }\end{array}$ & 0.87 & 0.96 \\
\hline Relevance & 0.94 & 0.98 \\
\hline $\begin{array}{l}\text { 1. Is it effective, in relation to what is proposed for } \\
\text { the families of children and adolescents with SCD, to } \\
\text { acquire knowledge about COVID-19? }\end{array}$ & 0.96 & 0.98 \\
\hline $\begin{array}{l}\text { 2. Is the brochure relevant for the guidance of } \\
\text { families of children and adolescents with SCD on the } \\
\text { prevention of COVID-19? }\end{array}$ & 0.96 & 0.98 \\
\hline $\begin{array}{l}\text { 3. Is the brochure relevant to the care provided by } \\
\text { nurses to patients? }\end{array}$ & 0.92 & 0.98 \\
\hline $\begin{array}{l}\text { 4. Does this brochure allow transferring relevant } \\
\text { information about COVID- } 19 \text { between nurse } \\
\text { practitioners and families of children and } \\
\text { adolescents with SCD? }\end{array}$ & 0.92 & 0.98 \\
\hline Global CVC & 0.92 & 0.98 \\
\hline
\end{tabular}


As for the "Is the information well structured in terms of concordance and spelling?" item, A CVC of 0.85 was totaled. There was reallocation and condensation to enable the expression of a single idea, to facilitate the understanding and adaptation of the vocabulary, without generating ambiguities.

In"structure and presentation", in the "Are the images adequate?" item, Although it presented a CVC of 0.85. A judge recommended inserting the image, demonstrating the correct use of the mask and sequence for correct hand washing. In order to make the suggestion effective, the authors elaborated image 1 (correct use of the mask) and image 2 (simple hand washing).

It is worth noting that judges'suggestions in the first round (Delphi l) for the items that needed to be revised were regarding their form of presentation, exclusion, reallocation and inclusion of illustration.

The judges suggested, as changes in the Delphi Il technique, inserting a black stripe in the child's eyes in image 1 , in order to guarantee ethical precepts and reduce the font size in the references, both were accepted; the result obtained from the CVC regarding the item "objectives" was equal to 0.96; in "structure and presentation", 0.97; in "relevance", 0.98. Global CVC scored 0.98, ensuring the brochure content and appearance validity for use in the target population.

The judges brought as comments the ET's excellent proposal to approach families of children/adolescents with SCD and COVID-19, a disease that is often neglected and little known by health professionals, arousing the need for greater knowledge of professionals.

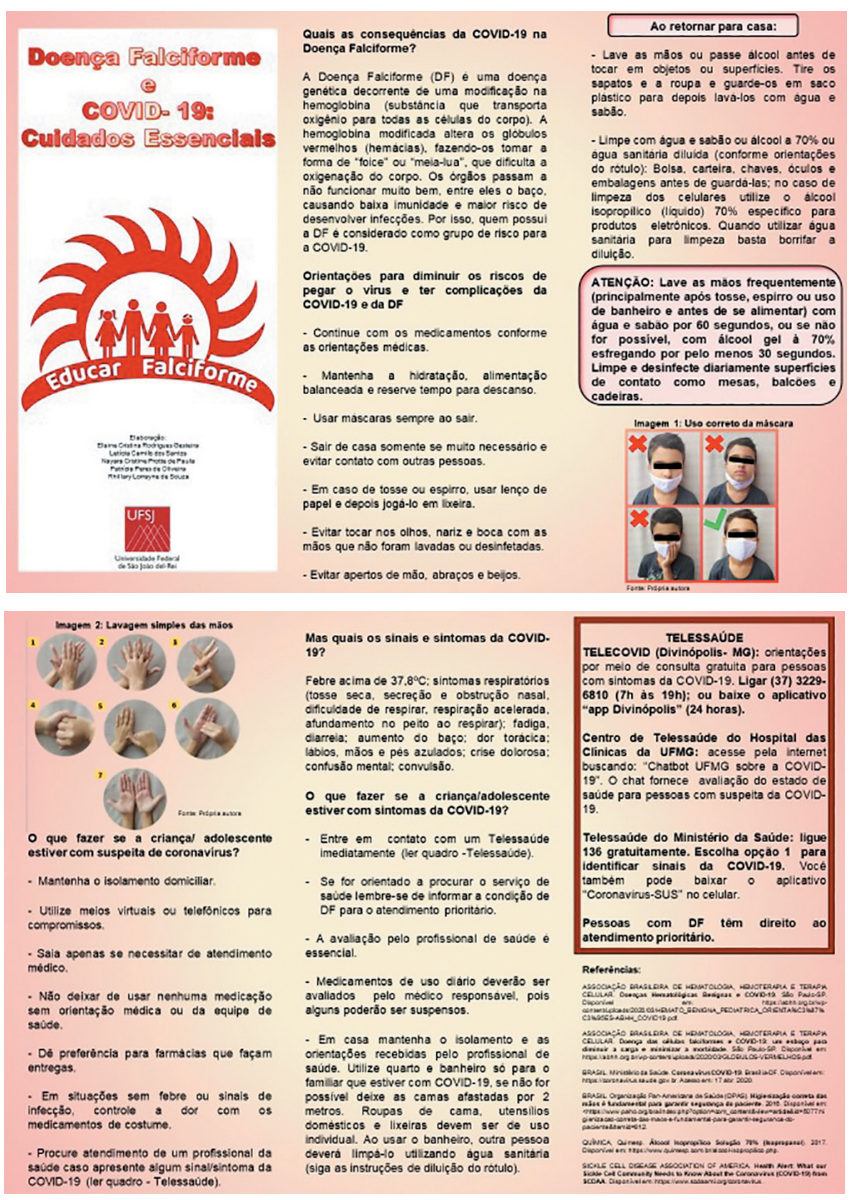

Figure 1 - Final version of educational technology on COVID-19 and essential care for families of children/adolescents with sickle cell disease validated by judges and families, Divinópolis, Minas Gerais, Brazil, 2020
After the changes proposed by the judges were completed and the brochure was finalized, the pilot test began. Two members of each of the six families participated, three with at least one child with SCD and another three families with an adolescent with SCD.

Participants responded to the ET assessment instrument involving questions pertinent to objectives (CVC $=1.00)$, organization $(C V C=1.00)$, writing style $(C V C=0.98)$, appearance $(C V C=1.00)$, and motivation $(C V C=1.00)$. It was preferred to maintain the use of CVC for purposes of reliability in the results. The global CVC was 0.99 , with the target population proving content validity and appearance. Families did not suggest changes in the ET.

Figure 1 shows the ET's final version on COVID-19 and the essential care for families of children/adolescents with SCD, validated in terms of content and appearance by judges and families participating in the pilot test.

\section{DISCUSSION}

The ET construction and validation on COVID-19 and the essential care for families of children/adolescents with SCD was developed with methodological rigor, to enable scientific knowledge to be accessible to nursing practitioners who work with these people.

In this study, the significant experience of the judges participating in validation stands out, $83.33 \%$ of whom were doctors with great experience in assisting people with SCD and in teaching. In this perspective, literature exposes that master's and doctoral degrees holders are largely responsible for enabling repercussions in practices and, therefore, in the advancement of nursing ${ }^{(15)}$.

A study pointed out that Brazilian nurses holding master's and doctoral degrees, i.e., some type of stricto sensu graduate-type, are in a reality that is guided by policies that solidify and originate innovations in their activities, in order to obtain socio-political impacts, educational, scientific and technological relevance to health ${ }^{(16)}$.

That said, it is understood that the participation of experienced and involved professionals in the field of teaching, research and care is relevant for the assessment of a brochure to be applied in practice, as proposed in this study, when constructing and validating the ET on COVID -19 and essential care for families of children/adolescents with SCD.

The validation process involved the participation of 12 judges in the Delphi I (DI) technique and 11 of these judges in Delphi II (DII). Reliability and validity are essential criteria for assessing the quality of an instrument ${ }^{(11)}$. Regarding the Delphi technique used to acquiesce consultation with a group of expert judges on the subject, the objective was not to deduce a simple answer or reach only a consensus, but quality opinions and responses were collected for a given research presented to a panel of experts, as recommended by the theoretical and methodological framework ${ }^{(10)}$.

In the ET validation, the judges presented a significant coefficient of agreement in all the assessed items, in order to make the instrument valid in relation to the brochure's objectives, structure, presentation, relevance, and content ${ }^{(9)}$.

People with SCD require a lot of vigilance during the current COVID-19 pandemic. As a vulnerable group, the English government's recommendations emphasized that individuals with SCD isolate themselves for much longer than the general population ${ }^{(6)}$. 
However, prolonged periods of blockage and the consequent lack of physical activity can increase the risk of complications. Furthermore, there are challenges in providing regular treatment for everyone with SCD, such as the significant reduction in voluntary blood donations during this period of the pandemic caused by the new coronavirus ${ }^{(6,17)}$.

It is noteworthy that individuals with SCD present multiple challenges, due to the complexity of their condition: comorbidities related to the disease and the need for frequent medical interventions and COVID-19 presenting high transmissibility; a large contingent of infected and sick people at the same time represents a risk of overload for the assistance of symptomatic and serious patients, which can cause strangulation of the health system and significantly increase the lethality of the disease ${ }^{(18-19)}$.

Among the guidelines the families of children/adolescents with SCD, to reduce the risks of contracting the virus and to have complications from COVID-19, the continuity of medications was included, according to medical guidelines, maintaining hydration, balanced nutrition and the reservation of periods for rest. SCD, a hematological condition that leads to functional asplenia, puts patients at greater risk of developing complications ${ }^{(5,20)}$.

Individuals with SCD and their families need to be instructed to drink plenty of fluids (two liters per day) in order to promote good hydration and diuresis, in addition to adequate food from a qualitative and quantitative point of view, with regular meals and regular use of prescribed medications ${ }^{(19)}$. There are variants that directly influence the evolution of SCD and its prognosis, such as access to medical care, good quality food and nutrition, access to basic sanitation and, therefore, good quality water and less exposure to infections, better living conditions and work, in addition to the rapid treatment of complications and infections, including those caused by Sars-CoV-2 ${ }^{(20-22)}$.

A study, which described clinical and pathological characteristics, management and results of the first 10 cases of individuals with SCD and infection by COVID-19 who were treated in a UK institution, stated that the result of infection by COVID-19 was favorable for these people, except those with significant pre-existing comorbidities. The study strongly advocated social detachment, according to public health guidelines, in addition to improved thromboprophylaxis for hospitalized patients ${ }^{(19)}$.

Recently, two other studies with isolated cases of acute chest syndrome in patients with SCD positive for COVID-19 have been reported $^{(20-21)}$. It is noteworthy that, currently, there is little clinical experience of individuals infected with Sars-CoV-2 with SCD, but data suggest that pediatric patients with COVID-19 have a milder clinical course compared to adults; however, thrombosis and complications have been described ${ }^{(21)}$. For this reason, it is believed that certain recommendations should be followed by people with SCD and their families.

Therefore, the guidelines contained in the ET are essential to reduce the risks of contracting Sars-CoV-2 and to have complications from COVID-19 and SCD, since, with the development of the current pandemic, people with SCD and their families require specific guidance on isolation and changes to the usual treatment regimens.

Outpatient visits should be reduced for most people with SCD, however, some tests, such as the first transcranial dopplers for children with SCD, should not be postponed, as the known risk of stroke outweighs the unknown risk of COVID- $19^{(8)}$. Blood transfusion programs must be continued, but specific changes in the flow of care need to be instituted in order to reduce the risk of patient exposure to COVID-19, as well as contingency planning for possible reductions in blood available for transfusions ${ }^{(8,22)}$.

With regard to guidelines in the case of a child/adolescent with suspicion or symptoms of COVID-19, evidence has pointed out that the use of telehealth can bring benefits, such as the reduction in the time of attendance, reduction in the circulation of people in health establishments, reduction of the spread of the disease and the risk of contamination of individuals, in addition to the opening of care places in Emergency Care Units and in hospitals ${ }^{(20,23)}$.

Technological improvements and cost reduction of telehealth solutions, combined with high-speed internet and the mass dissemination of smartphones, make it possible to apply this structure and quickly deploy tele video consultations in a person's home ${ }^{(24)}$.

Thus, in its multiple and diversified applications in the field of health promotion, assistance and education, telehealth is a primary tool for coping with the Sars-CoV-2 virus pandemic. The Ministry of Health of Brazil published Ordinance 467 of March 23, 2020 , providing for telemedicine actions in the operationalization of measures to fight the epidemic, approving its practice in the public and private spheres. According to the Ordinance, telehealth can be used, exceptionally, in actions that consider pre-clinical care, consultation, monitoring, care support and diagnosis within the Unified Health System (SUS - Sistema Único de Saúde), supplementary and private health ${ }^{(25)}$.

Telehealth is an important element in increasing the capacity to fight COVID-19; concomitantly keeps health services functioning and safer ${ }^{(24)}$. It is also conjectured, as an effective option, the one-to-one visits of people with other health care needs, helping to preserve services for those who need assistance most ${ }^{(18,24)}$.

Regarding ET, it is noteworthy that none of the items reached a CVC below 0.81. The judges recognized that ET can contribute to the health education process (DII, CVC $=0.98$ ), which is effective for maintaining self-care related to COVID-19 for families of children and adolescents with SCD (DII, CVC = 0.98). The ET can be implemented in the daily clinical practice of nurses working in the area of hemoglobinopathies (DII, CVC $=0.91$ ), allowing the transfer of relevant information about COVID-19 between nurses and the families of children/adolescents with SCD (DII, CVC $=0.98$ ), being a relevant instrument for the care provided by professionals (DII, CVC $=0.98$ ). On the other hand, the families participating in the pilot study considered the brochure to be organized, with excellent appearance and motivator (CVC $=0.99$ ).

Motivation is a psychological factor, conscious or not, that encourages the person to perform certain actions or goals. In this regard, it represents a stimulus that leads individuals to aim at the achievement of a certain objective, and is one of the most influential forces in changing behavior ${ }^{(9)}$.

It is emphasized that, in order to save lives, it is essential not only that people with Sars-CoV-2 infection are properly identified and treated, but also that individuals with other diseases, including bacterial infection, are quickly recognized and treated appropriately. Additionally, a balance must be struck between 
canceling non-urgent procedures, to reduce unnecessary contact with the hospital and to minimize the risk of viral transmission and to provide the necessary treatment for the underlying condition ${ }^{(8)}$.

Finally, national and international efforts should be made to study the effects of COVID-19 infection on this group of patients, in addition to developing evidence about treatment so that care for future patients can be optimized.

The ET developed in this study has the job of reinforcing verbal information, acting as a guide for orienting cases of later doubts and assisting in decision making. For this, it was built and validated, with the intention of being used effectively ${ }^{(8,26)}$.

\section{Study limitations}

The limitation of this study is related to the low number of responses from the experts. However, it is noteworthy that the sample of judges was constituted by a number considered adequate according to the criteria proposed by Pasquali(11).

\section{Contributions to nursing}

It is considered that "Sickle cell disease and COVID-19: essential care" will allow health professionals to offer assistance consistent with the needs of families of children and adolescents with SCD, as well as complement guidance and clarifications on the management of SCD in pandemic times due to COVID-19. Moreover, studies in the context of home care are in line with international efforts to improve the activities of hematological nurses. In Brazil, there is a lack of studies that address the care of people with SCD with scientific evidence. Thus, it is believed that the elaboration of an ET will substantially collaborate to reinforce nurses' attention to the families of children and adolescents with SCD.

\section{CONCLUSION}

The results obtained in the study of the ET construction and validation on COVID-19 and the essential care for families of children/adolescents with SCD indicated psychometric properties acceptable for its use in health services, with a global CVC after the DIl round equal to 0.98 , which indicates an excellent level of agreement among judges. Agreement among judges provided evidence for the reliability of the brochure, with changes to the items they recommended. The instrument assessment was measured with a significant outcome, following Delphi's methodological rigor.

In association, the target population considered the ET useful in terms of its objectives, its organization, its writing style, its appearance and its motivation, reaching a global CVC of 0.99 .

Thus, clinical validation in subsequent studies is expected to be carried out to assess the efficiency of the ET constructed and validated as a facilitator in assisting children and adolescents with SCD.

\section{REFERENCES}

1. Souza RC, Miranda Neto PAD, Santos JRF, Monteiro SG, Gonçalves MC, Silva FB, et al. Sickle cell anaemia prevalence among newborns in the Brazilian amazon-savanna transition region. Int J Environ Res Public Health. 2019;16(9):1638. https://doi.org/10.3390/ijerph16091638

2. Dexter D, Simons D, Kiyaga C, Kapata N, Ntoumi F, Kock R, et al. Mitigating the effect of the COVID-19 pandemic on sickle cell disease services in African countries. Lancet Haematol. 2020;7(6):e430-e432. https://doi.org/10.1016/S2352-3026(20)30122-8

3. Piel FB, Steinberg MH, Rees DC. Sickle cell disease. N Engl J Med. 2017;376:1561-73. https://doi.org/10.1056/NEJMra1510865

4. Carneiro-Proietti ABF, Kelly S, Miranda Teixeira C, Sabino EC, Alencar CS, Capuani L, et al. Clinical and genetic ancestry profile of a large multi-centre sickle cell disease cohort in Brazil. Br J Haematol. 2018;182(6):895-908. https://doi.org/10.1111/bjh.15462

5. Hussain FA, Njoku FU, Saraf SL, Molokie RE, Gordeuk VR, Han J. COVID-19 infection in patients with sickle cell disease. Br J Haematol. 2020;189(5):851-52. https://doi.org/10.1111/bjh.16734

6. Sivalingam T, Inusa B, Doyle P, Oteng-Ntim E. COVID-19 and the pulmonary complications of sickle cell disease. E J Haem. 2020;1 (2):545-47. https://doi.org/10.1002/jha2.105

7. DeBaun MR. Initiating adjunct low dose-hydroxyurea therapy for stroke prevention in children with SCA during the COVID-19 pandemic. Blood. 2020;135(22):1997-99. https://doi.org/10.1182/blood.2020005992

8. Roy NBA, Telfer P, Eleftheriou P, De la Fuente J, Drasar E, Shah F, et al. Protecting vulnerable patients with inherited anaemias from unnecessary death during the COVID-19 pandemic. Br J Haematol. 2020;189(4):635-39. https://doi.org/10.1111/bjh.16687

9. Perdigão MMM, Rodrigues AB, Magalhães TL, Freitas FMC, Bravo LG, Oliveira PP. Educational technology for fatigue management related to antineoplastic chemotherapy. Rev Bras Enferm. 2019;72(6):1519-25. https://doi.org/10.1590/0034-7167-2018-0505

10. Doak CC, Doak LG, Root JH. Teaching patients with low literacy skills. 2nd ed. Philadelphia: JB Lippincott; 1996.

11. Pasquali L. Instrumentação psicológica: fundamentos e práticas. Porto Alegre: Artmed; 2010.

12. Aguiar LL, Guedes MVC, Galindo-Neto NM, Melo GAA, Almeida PC, Oliveira RM, et al. Validação de instrumento de avaliação da segurança de pacientes renais em hemodiálise. Acta Paul Enferm. 2018;31(6):609-15. https://doi.org/10.1590/1982-0194201800084

13. Fehring RJ. The Fehring model. In: Carrol-Johnson RM, Paquette M. Classification of nursing diagnoses: proceedings of the tenth conference of North American Nursing Diagnosis Association. Philadelphia: Lippincott; 1994.

14. Zaccaron R, D'Ely RCSF, Xhafaj DCP. Estudo piloto: um processo importante de adaptação e refinamento para uma pesquisa quase experimental em aquisição de L2. Rev GELNE. 2018;20(1):30-1. https://doi.org/10.21680/1517-7874.2018v20n1ID13201 
15. Melo JM, Oliveira PP, Rodrigues AB, Souza RS, Fonseca DF, Gontijo TF, et al. Bundle construction and assessment before antineoplastic extravasation: a methodological study. Acta Paul Enferm. 2020;33:eAPE20190075. https://doi.org/10.37689/ acta-ape/2020AO0075

16. Scochi CGS, Munari DB, Gelbcke FL, Erdmann AL, Gutiérrez MGR, Rodrigues RAP. The strict sense nursing postgraduation in Brazil: advances and perspectives. Rev Bras Enferm. 2013;66(Spe):80-9. https://doi.org/10.1590/S0034-71672013000700011

17. Wu Z, McGoogan JM. Characteristics of and important lessons from the coronavirus disease 2019 (COVID-19) outbreak in China: summary of a report of 72,314 cases from the Chinese Center for Disease Control and Prevention. JAMA 2020;323(13):1239-42. https://doi.org/10.1001/ jama.2020.2648

18. Caetano R, Silva AB, Guedes ACCM, Paiva CCN, Ribeiro GR, Santos DL, et al. Challenges and opportunities for telehealth during the COVID-19 pandemic: ideas on spaces and initiatives in the Brazilian context. Cad Saúde Pública. 2020;36(5):e00088920. https://doi. org/10.1590/0102-311x00088920

19. Menapace LA, Thein SL. COVID-19 and sickle cell disease. Haematologica. 2020;105(11):2501-4. https://doi.org/10.3324/haematol.2020.255398

20. McCloskey KA, Meenan J, Hall R, Tsitsikas DA. COVID-19 infection and sickle cell disease: a UK centre experience. Br J Haematol. 2020;190(2):e57-e58. https://doi.org/10.1111/bjh.16779

21. Taher AT, Bou-Fakhredin R, Kreidieh F, Motta I, Franceschi L, Cappellini MD. Care of patients with hemoglobin disorders during the COVID-19 pandemic: an overview of recommendations. Am J Hematol. 2020;95(8):E208-E210. https://doi.org/10.1002/ajh.25857

22. Beerkens F, John M, Puliafito B, Corbett V, Edwards C, Tremblay D. COVID-19 pneumonia as a cause of acute chest syndrome in an adult sickle cell patient. Am J Hematol. 2020. https://doi.org/10.1002/ajh.25809

23. Nur E, Gaartman AE, van Tuijn CFJ, Tang MW, Biemond BJ. Vaso-occlusive crisis and acute chest syndrome in sickle cell disease due to 2019 novel coronavirus disease (COVID-19). Am J Hematol. 2020;95(6):725-26. https://doi.org/10.1002/ajh.25821

24. Ohannessian R, Duong TA, Odone A. Global Telemedicine implementation and integration within health systems to fight the COVID-19 pandemic: a call to action. JMIR Public Health Surveill 2020;6:e18810. https://doi.org/10.2196/18810

25. Ministério da Saúde (BR). Portaria MS n 467, de 20 de março de 2020. Dispõe, em caráter excepcional e temporário, sobre as ações de Telemedicina, com o objetivo de regulamentar e operacionalizar as medidas de enfrentamento da emergência de saúde pública de importância internacional previstas no art. $3^{\circ}$ da Lei n 13.979, de 6 de fevereiro de 2020, decorrente da epidemia de COVID-19. Diário Oficial da União 2020; 23 março.

26. Benevides JL, Coutinho JFV, Pascoal LC, Joventino ES, Martins MC, Gubert FA, et al. Development and validation of educational technology for venous ulcer care. Rev Esc Enferm USP. 2016;50(2):306-12. https://doi.org/10.1590/S0080-623420160000200018 